\title{
When Did the Discussion of "Fixed Versus Floating Exchange Rates" Fall Out of Vogue?
}

\author{
Julia Jakus \\ Boğaziçi Üniversitesi
}

This brief article offers an overview of fixed and floating exchange rate systems and contextualizes how these systems have changed over the last several decades. The article critically questions why many higher educational institutions have yet to adapt some of the questions economic policy makers actually face by looking at pivotal moments over the last several decades. What does the international exchange rate system actually look like, what landmark moments led to the current dynamic and how does this differ from the black boxed concepts of exchange rates as taught in most intro university economics courses?

Keywords: fixed, pegged, floating, exchange rate systems, Pax Americana, Bretton Woods, currency

\section{INTRODUCTION}

When did the discussion of "Fixed versus Floating Exchange Rates" fall out of vogue? As vertically and horizontally intertwined economies have become the norm rather than the exception, the discourse on strictly fixed exchange rates is more of a history lesson than anything else. The discussion that once dominated the field of economics in the era of the Bretton Woods System (dismantled between 1968-73) where 44 signatories assented to peg their national currencies to the USD (valued then at \$35 USD per every ounce of gold) has become something more foundational than ground-breaking (The Balance, 2019).

While it is wholly important to educate individuals how and why these decades shaped the current financial system, it is even more important to impart that the financial architecture which we have come to know, even in the post-Bretton Woods era is already becoming antiquated, particularly given the rise of Blockchain tech (more on this in the next article). But before jumping into the reasons why the "Fixed versus Floating" debate has less and less to offer, let's look at the genesis of its decline in the early 1970s.

\section{The Timeline: From Pax Americana to the Present}

The Fixed Exchange Rate system was dissolved after the US dollar was devalued by Nixon to from $1 / 35$ ( 1 ounce of gold valued at 35 US dollars) to $1 / 38$ to the ounce, and soon thereafter to $1 / 42$ in response to domestic stagflation in the United States. This devaluation sparked an international run on the US gold reserves, and the system was abolished before it hit rock bottom. In spite of this, the US dollar continued to function as the international reserve currency largely because the institutions for such a system had been in place since the end of the Second World War (The Balance, 2019). The width and depth of these institutions were so far-reaching that it was likened to neo-imperialism, the Pax Americana (Quadrant.org.au, 2019) The "Fixed versus Floating debate" peaked when the world was faced with economically integrating former command economies in the aftermath of the Cold War (1989) (Layne, 
2019). Likewise, in the absence of bipolarity, the influence of the Pax Americana began to wane. (Europenowjournal.org, 2019). By the turn of the millennium, the gold standard of earlier decades had disappeared, and the Bretton Woods fixed-exchange-rate system had fully dissolved but the International Monetary Fund (also established in 1945) persisted. Additionally, the end of the Cold War in 1989, the integration of the former command economies throughout the 1990s, and the gradual waning of the Pax Americana in the wake of all of these events have collectively and fundamentally changed the way global economies interact (World Gold Council, 2019). Of course, the historically formative weight that the "Fixed versus Floating" discourse has had upon the global political economy is indeed significant for those wishing to understand the bifurcation of fiscal and monetary policy associated with each path. Why then, does the debate itself carry little relevance today? We could start by rephrasing the question: How many countries are on a fixed rate exchange system right now?

\section{The Current System: Who's Fixed, Pegged, or Floating?}

Currently, there are thirty-nine (39) currencies that have pegged their worth to another value source (The Balance, 2019). Specifically, fifteen countries (15) are pegged to the USD (Aruba, Bahamas, Bahrain, Barbados, Curacao and Sint Maarten, Djibouti, Eritrea, Hong Kong, Iraq, Jordan, Lebanon, Oman, Qatar, Saudi Arabia, Turkmenistan, UAE). Nineteen (19) are tied to the Euro (Bosnia and Herzegovina, Bulgaria, Comoros, Denmark, Sao Tome and Principe plus fourteen Central and Western African Nations). Two (2) countries are linked to the Indian Rupee (Bhutan, Nepal), two (2) more to the South African Rand (Lesotho, Namibia), and one (1) to the Singapore Dollar (Brunei), (The Balance, 2019).

Among the fourteen Central and Western African countries who use common fixed currencies, seven African countries are tied to the Central African CFA franc (Cameroon, Central African Republic, Chad, Equatorial Guinea, Gabon, and the Republic of the Congo). An additional seven countries are linked to the Western African CFA franc (Benin, Burkina Faso, Guinea-Bissau, Ivory Coast, Mali, Niger, Senegal, and Togo). All of these are pegged to the euro at 655.957 to the euro (The Balance, 2019). One item to note: the tally above does not consider the Eurozone nations, because their EU monetary policy is collectively, not externally, determined (European Commission - European Commission, 2019). Additionally, it does not consider countries, such as El Salvador or Zimbabwe, who have fully forfeited their national currency in favor of the USD.

\section{Key Take Aways}

The most important take-away from all of this is that none of these currencies are actually operating under a strictly fixed exchange rate system. This is because the currencies they are pegged to are in various degrees of a managed float. In effect, they have simply tied themselves to a different mast, surrendering any domestic control over their interest and exchange rates.

Likewise, because the rate of capital flow is exponentially increasing, greater quantities of financial flows are decentralizing, and because economic institutions have only become more interdependent since the end of the Second World War, the situation of today's global political economy is more integrated than ever before. In sum, in spite of the esteemed exchange rate ethos that is whipped into economics students worldwide by instructors seeking to revive the relevance of the "Fixed versus Floating" deliberation, the actual contested aspects of the debate itself have fizzled into near irrelevance. 


\section{REFERENCES}

European Commission - European Commission. (2020). What is the euro area? Retrieved October 12, 2020, from https://ec.europa.eu/info/business-economy-euro/euro-area/what-euro-area_en

Europenowjournal.org. (2020). America First and the End of Pax Americana. Retrieved October 12, 2020, from https://www.europenowjournal.org/2018/11/07/america-first-and-the-end-of-paxamericana/

Layne, C. (2020). The End of Pax Americana: How Western Decline Became Inevitable. The Atlantic. Retrieved October 12, 2020, from https://www.theatlantic.com/international/archive/2012/04/theend-of-pax-americana-how-western-decline-became-inevitable/256388/

The Balance. (2020). How a 1944 Agreement Created a New World Order. Retrieved October 12, 2020, from https://www.thebalance.com/bretton-woods-system-and-1944-agreement-3306133

Quadrant.org.au. (2020). Pax Americana and US Decline - Quadrant Online. Retrieved October 12, 2020, from https://quadrant.org.au/magazine/2012/03/pax-americana-and-us-decline/

World Gold Council. (2020). The Bretton Woods system. Retrieved October 12, 2020, from https://www.gold.org/about-gold/history-of-gold/bretton-woods-system 